\title{
Replacement demand forecasts by occupation and education
}

Citation for published version (APA):

Willems, E. J. T. A., \& de Grip, A. (1990). Replacement demand forecasts by occupation and education. Researchcentrum voor Onderwijs en Arbeidsmarkt, Faculteit der Economische Wetenschappen. ROA Working Papers No. 7E https://doi.org/10.26481/umarow.199007E

Document status and date:

Published: 01/01/1990

DOI:

10.26481/umarow.199007E

Document Version:

Publisher's PDF, also known as Version of record

\section{Please check the document version of this publication:}

- A submitted manuscript is the version of the article upon submission and before peer-review. There can be important differences between the submitted version and the official published version of record.

People interested in the research are advised to contact the author for the final version of the publication, or visit the DOI to the publisher's website.

- The final author version and the galley proof are versions of the publication after peer review.

- The final published version features the final layout of the paper including the volume, issue and page numbers.

Link to publication

\footnotetext{
General rights rights.

- You may freely distribute the URL identifying the publication in the public portal. please follow below link for the End User Agreement:

www.umlib.nl/taverne-license

Take down policy

If you believe that this document breaches copyright please contact us at:

repository@maastrichtuniversity.nl

providing details and we will investigate your claim.
}

Copyright and moral rights for the publications made accessible in the public portal are retained by the authors and/or other copyright owners and it is a condition of accessing publications that users recognise and abide by the legal requirements associated with these

- Users may download and print one copy of any publication from the public portal for the purpose of private study or research.

- You may not further distribute the material or use it for any profit-making activity or commercial gain

If the publication is distributed under the terms of Article $25 \mathrm{fa}$ of the Dutch Copyright Act, indicated by the "Taverne" license above, 


\section{REPLACEMENT DEMAND FORECASTS \\ BY OCCUPATION AND EDUCATION}

ROA-W-1990/7E

E.J.T.A. Willems, A. de Grip

RESEARCH CENTRE FOR EDUCATION AND LABOUR MARKET

Faculty of Economic Sciences

Rijksuniversiteit Limburg

Maastricht, December 1990 
Willems, E.J.T.A.

Replacement demand forecasts by occupation and education / E.J.T.A. Willems, A. de Grip. Maastricht : Research Centre for Education and Labour Market, Faculty of Economic Sciences, Rijksuniversiteit Limburg. - (Report / Research Centre for Education and Labour Market, ISSN 0922-8098; 1990/7E)

Vert. van: Vervangingsvraagprognoses naar beroep en opleiding. - Maastricht : Researchcentrum voor Onderwijs en Arbeidsmarkt, Faculteit der Economische Wetenschappen, Rijksuniversiteit Limburg, 1990. - (Rapport / Researchcentrum voor Onderwijs en Arbeidsmarkt ; 1990/7). - Met lit. opg.

ISBN 90-5321-059-8 in spiraalband

Trefw.: vervangingsvraag; arbeidsmarkt. 


\section{CONTENTS}

1. INTRODUCTION

2. REPLACEMENT DEMAND: A THEORETICAL FRAMEWORK

3. REPLACEMENT DEMAND BY OCCUPATIONAL GROUP 5

3.1. Data and method 5

3.2. The historical replacement demand: a stylized example 9

3.3. A forecasting method for future replacement demand 10

$\begin{array}{ll}\text { 3.4. The forecast results } & 15\end{array}$

4. REPLACEMENT DEMAND BY EDUCATIONAL TYPE 17

5. CONCLUSION 19

$\begin{array}{lr}\text { REFERENCES } & 20\end{array}$

APPENDIX A: RESULTS REPLACEMENT DEMAND BY OCCUPATIONAL GROUP 21

APPENDIX B: RESULTS REPLACEMENT DEMAND BY EDUCATIONAL TYPE 23 


\section{ACKNOWLEDGEMENTS}

This study was conducted as part of a research assignment, extending over several years Project Education Labour Market, granted by the Ministry of Education and Sciences to the Research Centre for Education and the Labour Market. The assignment covers the development of an information system for education and the labour market, which may be used, among other things, to support the educational and occupational choices of students in secondary and tertiary education.

The research presented here relates to the development of a forecasting method for determining future replacement requirement. A distinction may be made here between the replacement demand per occupational group and the replacement demand per type of education.

The research was conducted by Drs. E.J.T.A. Willems, under the guidance of Dr. A. de Grip. Prof. Dr. J.A.M. Heijke and Drs. R.J.P. Dekker provided valuable advice. 


\section{INTRODUCTION}

As part of the Project Education Labour Market, extending over several years, the Research Centre for Education and Labour Market (ROA) is working on the development and further improvement of an information system for education and the labour market (see ROA, 1990). The results of component studies relating to the modelling of the expansion demand per occupational group (see Dekker, De Grip and Heijke, 1988) and the expansion demand per type of education (see Beekman, De Grip and Heijke, 1989) have already been published. Both forecasting models are being further developed (see Peeters, 1990). For many occupational groups and types of education the future replacement requirement are at least as important as the demand due to expansion. A forecasting method for determining the future replacement demand is developed in this working paper. The forecast results have been used in the labour market module of the Information System on Education and Employment I-See! (1990 version). This is a system for educational and occupational choice, released on CD-ROM (see also Dekker, De Grip, Beekman, Van de Loo, Wieling and Willems, 1990). These forecast results have also been used in ROA's policy report on the information system for education and the labour market, which is still to be published.

The replacement demand per occupational group, in combination with the expansion demand, gives a figure for jobs for newcomers, which we will call the number of 'job-openings'. In decisions regarding educational and occupation choices, this figure for job-openings may serve as an indicator of the likelihood of finding a job in a certain occupational group. In this way changes in employment levels, as well as the replacement demand as a result of the departure of workers, especially older employees and married women, and movements between occupational groups, are taken into account.

One of the main goals of the information system for education and the labour market is to give a (qualitative) characterization of the labour market prospects for school leavers or graduates for a given type of education. This is brought about by correlating the total future supply of newcomers on the labour market with the total future demand. Along with the expansion demand, replacement demand is often very important in determining the total demand. Replacement demand per education type is the result of permanent departures from the labour force due to retirement, the early retirement scheme, and other such reasons on the one hand, and of (temporary) withdrawals, especially on the part of married women due to birth and childrearing, on the other hand. However, occupational mobility has no influence on the replacement demand per type of education. Changing the field of work does not affect the educational structure of employment. 
$-2-$

The remainder of this working paper is structured as follows. In chapter 2 the theoretical framework for determining replacement demand is discussed. Chapter 3 fills this framework in in more detail, in order to determine the future replacement demand per occupational group. Because of the unavailability of suitable individual data on the processes of mobility at a relatively low level of aggregation over the full width of the labour market, it is necessary to make some suppositions. In section 3.1. the data employed is gone into and the method is explained with a mathematical model. In section 3.2. the replacement requirements in an historical period will be measured, using a stylized example. In section 3.3. a forecasting method for the future replacement demand is discussed, while section 3.4. will briefly examine the results. The replacement demand per type of education is dealt with in chapter 4 , and chapter 5 contains a short conclusion to this working paper. 


\section{REPLACEMENT DEMAND: A THEORETICAL FRAMEWORK}

In the labour market, mobility processes may be observed continuously. Many employees change occupation or job several times during their working life'. Moreover, every year a considerable number of people enter or leave the work force. Therefore a typical career path might begin with leaving regular day-time education and entering the work force, possibly after a period of unemployment. After having changed jobs several times, possibly with some periods of unemployment or a temporary withdrawal from the labour market, the worker finally leaves the work force later in life.

Figure 1. Input-output table showing currents of mobility in the labour market.

\begin{tabular}{|c|c|c|c|c|c|}
\hline$t-1$ & Job1 .... Job I & Unemployed & $\begin{array}{l}\text { Outside } \\
\text { labour force }\end{array}$ & $\begin{array}{l}\text { Outflow } \\
\text { population }\end{array}$ & Total \\
\hline $\begin{array}{c}\text { Job } 1 \\
\cdot \\
\cdot \\
\cdot \\
\text { Job I }\end{array}$ & A $\quad$ B & C & D & & $\begin{array}{c}\mathrm{W}_{\mathrm{A}-1} \\
\cdot \\
\cdot \\
\cdot \\
\mathrm{W}_{\mathrm{h}-1}\end{array}$ \\
\hline $\begin{array}{l}\text { Unemployed } \\
\text { Outside } \\
\text { labour force }\end{array}$ & $\begin{array}{l}\mathrm{F} \\
\mathrm{G}\end{array}$ & & & & \\
\hline $\begin{array}{l}\text { Inflow } \\
\text { population }\end{array}$ & & & & & \\
\hline Total & $W_{1 t} \ldots . \quad W_{k}$ & & & & \\
\hline
\end{tabular}

In figure 1 an input-output table for the entire population is presented, in which the mobility processes described above are schematically reproduced at an aggregated level. The last column of the input-output table gives the number of workers at time $t-1$ in each of the 'jobs' ${ }^{2}$ which have been differentiated, and also the number of unemployed and non-active people at the same moment. The last row of the table gives the same figures, for time $t$. In addition, the last column of the table gives the total population influx as a result of birth and immigration,

1. According to Allaart, Kunnen and Van Stiphout (1989) the total occupational mobility in the period October 1987 to October 1988 was $13 \%$.

2. In the practical application of this theoretical framework, occupational group and type of education replace the term 'job'. 
while the last row gives the total outflow of population due to death and emigration.

The inner part of the input-output table contains the flows of mobility within the labour market. Some of these flows are indicated by the capital letters A to G. 'Flow' A, for instance, indicates the number of employees that kept working in job 1 during the period $(t-1, t)$. The flows $B$ and $E$ represent job-to-job mobility. The flows $C$ and $D$ represent departures from employment, to unemployment and non-availability respectively. The latter indicates changes such as retirement and the voluntary exit of, in particular, married women. The group of unemployed who have found a job during the period $(t-1, t)$, is indicated by the letter $F$. Finally, flow $G$ refers to new positions gained by those who were not available for the labour market at time $t-1$, such as school leavers who find a job and women who re-enter the labour market.

With the aid of this theoretical framework the concepts of expansion demand and replacement demand may be defined. The expansion demand for job $i$ in the (historical) period $(t-1, t)$ is given by the difference in the number of workers at the two times:

$E D_{i t}=W_{i t}-W_{i t-1}$

where:

$E D_{\text {it }}$ the expansion demand in period $(t-1, t)$;

$W_{i t} \quad$ the number of workers in job $i$ at time $t$.

The replacement demand is then defined in relation to the expansion demand. Where there is a positive expansion demand (an increase in employment), the replacement demand is equal to the number of workers who leave a certain job during the period $(t-1, t)$. The vacancies that thus appear will have to be filled before there can be a rise in the total numbers employed. If the expansion demand is negative, meaning that there is a decrease in employment, not all of the vacancies created by departing employees are filled. Therefore the replacement demand is then not equal to the total of the departures from a certain job, but rather to the number of vacancies that are actually refilled, that is, the total influx of labour to the job in question. The concept of replacement demand can be explained further using figure 1. If there is an increase in employment, the replacement demand for job 1 is equal to the sum of the flows $B, C$ and $D$ (the total outflow). However, if employment in job 1 decreases, the sum of the flows $E, F$ and $\mathrm{G}$ flows (the total inflow) gives the replacement demand. 


\section{REPLACEMENT DEMAND BY OCCUPATIONAL GROUP}

\subsection{Data and method}

In chapter 2 the method of determining theoretical replacement requirements in the past was discussed. This entailed the assumption that individual data on the mobility processes in the labour market is available. Since the aim of this study is to determine the replacement demand for all the occupational groups and types of education distinguished within the ROA-information system, it is not possible to base the analysis on the available individual data. Therefore the aggregated data from the Labour Force Survey of the Central Bureau for Statistics (CBS) has to be used.

With the aid of a number of selection variables we can try to group the aggregated data in such a way that most of the mobility flows specified in figure 1 will be observable. The variables which could be used are those representing some personal characteristic, such as sex, age and educational background. However, because a large number of cells are not well filled, the data is only divided according to age and sex. This is expected to be sufficient to detect most of the mobility processes. After all, the flow into a certain occupational group consists mostly of young people, while the flow out consists mostly of older employees. By making a distinction according to sex, the exit and re-entrance (temporary or not) of women is also recorded to a significant extent.

In the remainder of this section we will first briefly discuss the data used, and then explain, with the aid of a mathematical model, how the replacement demand by occupational group can be determined.

\section{Data}

As has already been mentioned, the data used comes from the Labour Force Survey of the CBS, which gives the age structure by sex and occupational group for the years 1979 and $1985^{3}$. The workers in each occupational group are divided by sex, and by age into eleven age groups, each age-band covering five years.

Method

Using the data described above, a mathematical model can be formed to determine the

3. See respectively CBS (1982), table 30, p. 126 and CBS (1987), table 26, p. 99. 
replacement demand in the period $(t-1, t)$. The following variables are defined:

$\mathrm{W}_{\mathrm{ijt}}$ the number of workers in occupational group $\mathrm{i}$ of the age-band $\mathrm{j}$ at time $\mathrm{t}$;

$\mathrm{S}_{\mathrm{ijt}} \quad$ the number of workers in occupational group $\mathrm{i}$ of age $\mathrm{j}$ at time $\mathrm{t}-1$ who are still working in this occupational group at time $t$ (flow $A$ in figure 1);

$\mathrm{O}_{\mathrm{ijt}} \quad$ the flow of workers of age $\mathrm{j}$ at time $\mathrm{t}-1$ out of occupational group $\mathrm{i}$ during the period $(\mathrm{t}-$ $1, t$ ) (flows $B, C$ and $D$ in figure 1 );

$\mathrm{I}_{\mathrm{jit}} \quad$ the flow of workers of age $\mathrm{j}$ at time $\mathrm{t}$ into occupational group $\mathrm{i}$ during the period $(\mathrm{t}-1, \mathrm{t})$ (flows $E, F$ and $G$ in figure 1 ).

To avoid complicating the explanation unnecessarily, some simplifying assumptions are made in the presentation of the mathematical equations ${ }^{4}$ :

- $\quad$ only three age groups are distinguished $(j=1 . .3)$;

- the width of the age groups is the same as the length of the period $(t-1, t)$;

- the selection variable sex is left out.

If in addition the index $i$, for the occupational groups which are distinguished, is left out, the model is as follows:

$W_{1 t-1} \equiv S_{1 t}+O_{1 t}$

$W_{2 t-1} \equiv S_{2 t}+O_{2 t}$

$W_{3 t-1} \equiv O_{3 t}$

$W_{1 t} \equiv \quad I_{1 t}$

$W_{2 t} \equiv S_{1 t} \quad+I_{2 t}$

$W_{3 t} \equiv S_{2 t} \quad+I_{3 t}$

In equations (2) and (3) we see that some of those of a given age group, who were working at time t-1 $\left(\mathrm{W}_{\mathrm{jt}-1}\right)$, do not change their occupational group and are therefore still in the same occupational group at time $t$. In the equations this is marked by $S_{j t}$. Another part does change occupation, or retires from the labour market. This is indicated by $\mathrm{O}_{\mathrm{jt}}$. The oldest group of

4. These simplified suppositions were not made in the model used in the analysis itself. 
workers at time $t-1\left(W_{3 t-1}\right)$ will reach pensionable age in the period $(t-1, t)$ and will leave the work force altogether. This has been indicated in equation (4).

Equation (5) says that the youngest group of workers in this occupational group at time $t$ consists entirely of new arrivals in the labour market (school leavers). These have entered in the period $(t-1, t)\left(I_{1 t}\right)$. Equation (6) shows that the group of working people in age-group 2 consists of those employees who have not been mobile in the period $(t-1, t)$, plus those newly entering the work force. These groups of workers are designated by $S_{1 t}$ and $I_{2 t}$ respectively. The variable $S$ has the age index 1 , since these workers belonged to this age category at time t. Equation (7) is analogous to equation (6).

The equation system above may be reduced to:

$I_{1 t} \quad=W_{1 t}$

$I_{2 t}-O_{1 t}=W_{2 t}-W_{1 t-1}$

$I_{3 t}-O_{2 t}=W_{3 t}-W_{2 t-1}$

$$
-O_{3 t}=-W_{3 t-1}
$$

It should be said that, for a given age category, only the net effect of the flows in and out can be observed, since it is possible that part of the outflow is compensated for by a flow of workers of the same sex and the same age category in. The flows observed may therefore be described as the net outflow and the net inflow, the latter applying where the flow in is greater than the flow out. This means that no empirical distinction can be made between $\mathrm{I}_{2 \mathrm{t}}$ and $\mathrm{O}_{1 \mathrm{t}}$ and between $\mathrm{I}_{3 \mathrm{t}}$ and $\mathrm{O}_{2 \mathrm{t}}$. The net outflow for the age categories 1 and 2 can then be defined as:

$$
\begin{aligned}
O_{1 t}^{*} & =O_{1 t}-I_{2 t}=W_{1 t-1}-W_{2 t} & & \text { if } W_{2 t}-W_{1 t} \leq 0 \\
& =0 & & \text { otherwise } \\
O_{2 t}^{*} & =O_{2 t}-I_{3 t}=W_{2 t-1}-W_{3 t} & & \text { if } \quad W_{3 t}-W_{2 t} \leq 0 \\
& =0 & & \text { otherwise }
\end{aligned}
$$


and, by analogy, the net inflow for the age groups 2 and 3 is:

$$
\begin{aligned}
I_{2 t}^{*} & =I_{2 t}-O_{1 t}=W_{2 t}-W_{1 t-1} & & \text { if } W_{2 t}-W_{1 t}>0 \\
& =0 & & \text { otherwise } \\
I_{3 t}^{*} & =I_{3 t}-O_{2 t}=W_{3 t}-W_{2 t-1} & & \text { if } \quad W_{3 t}-W_{2 t}>0 \\
& =0 & & \text { otherwise }
\end{aligned}
$$

where:

$\mathrm{O}_{\mathrm{jt}}^{*} \quad$ the net outflow of workers of age $\mathrm{j}$ at time $\mathrm{t}-1$ in the period $(\mathrm{t}-1, \mathrm{t})$;

$I^{*}$ the net inflow of workers of age $j$ at time $t$ in the period $(t-1, t)$.

The equations (12) to (15) may be rewritten as:

$$
O_{1 t}^{*}=\max \left\{0 ; W_{1 t-1}-W_{2 t}\right\}
$$

$O_{2 t}^{*}=\max \left\{0 ; W_{2 t-1}-W_{3 t}\right\}$

$I_{2 t}^{*}=\max \left\{0 ; W_{2 t}-W_{1 t-1}\right\}$

$I_{3 t}^{*}=\max \left\{0 ; W_{3 t}-W_{2 t-1}\right\}$

We have seen in chapter 2 that the total replacement demand for a certain occupational group, where the employment level is rising, equals the total flow of workers out, and that the replacement demand equals the total flow of workers in, if the employment level is falling. If the concepts of inflow and outflow are interpreted as net inflow and outflow, replacement demand may be calculated as indicated in the equations (20) and (21):

$$
\begin{gathered}
W_{t}=\sum_{j} W_{j t} \geq \sum_{j} W_{j t-1}=W_{t-1} \Rightarrow R D_{t}=O_{1 t}^{*}+O_{2 t}^{*}+O_{3 t} \\
W_{t}=\sum_{j} W_{j t}<\sum_{j} W_{j t-1}=W_{t-1} \Rightarrow R D_{t}=I_{1 t}+I_{2 t}^{*}+I_{3 t}^{*}
\end{gathered}
$$


where:

$\mathrm{RD}_{\mathrm{t}} \quad$ replacement demand for an occupational group in the period $(t-1, t)$.

\subsection{The historical replacement requirement: a stylized example}

The method developed in section 3.1. to determine the replacement demand per occupational group will be further explained in this section by means of a simple example. Table 1 categorizes the workers of two occupational groups at times $t-1$ and $t$ by age.

Table 1. Division of employment for two occupational groups into age categories (example)

\begin{tabular}{ccccc}
\hline Age group & $\begin{array}{l}\text { Occupational group } \begin{array}{l}1 \\
\mathrm{t}-1\end{array} \\
\mathrm{t}\end{array}$ & \multicolumn{2}{c}{$\begin{array}{l}\text { Occupational group } 2 \\
\mathrm{t}-1\end{array}$} \\
$\mathrm{t}$ & 150 & 160 & 280 & 275 \\
2 & 200 & 220 & 130 & 100 \\
3 & 50 & 35 & 40 & 50 \\
Total & 400 & 415 & 450 & 425 \\
\hline
\end{tabular}

In this example occupational group 1 is a so-called growth occupation - the total employment has increased during the period $(\mathrm{t}-1, \mathrm{t})$ - and occupational group 2 is shrinking. The expansion demand over this period is +15 and -25 for the two groups respectively.

By means of the equations (16) to (21) the historical replacement requirement can be determined. For occupational group 1:

$$
\begin{aligned}
R D_{t} & =O_{1 t}^{*}+O_{2 t}^{*}+O_{3 t} \\
& =\max \left\{0 ; W_{1 t-1}-W_{2 t}\right\}+\max \left\{0 ; W_{2 t-1}-W_{3 t}\right\}+W_{3 t-1} \\
& =0+165+50 \\
& =215
\end{aligned}
$$

The replacement demand for occupational group 2 in period $(t-1, t)$ is: 


$$
\begin{aligned}
R D_{t} & =I_{1 t}+I_{2 t}^{*}+I_{3 t}^{*} \\
& =W_{1 t}+\max \left\{0 ; W_{2 t}-W_{1 t-1}\right\}+\max \left\{0 ; W_{3 t}-W_{2 t-1}\right\} \\
& =275+0+0 \\
& =275
\end{aligned}
$$

The net inflow is by definition equal to the sum of the net outflow and the expansion demand. The replacement demand for a declining group can therefore also be determined according to equation (22):

$$
R D_{t}=O_{1 t}^{*}+O_{2 t}^{*}+O_{3 t}+\left(\sum_{j} W_{j t}-\sum_{j} W_{j t-1}\right)
$$

The replacement demand for occupational group 2 is then calculated as:

$$
\begin{aligned}
R D_{t} & =180+80+40+(425-450) \\
& =275
\end{aligned}
$$

\subsection{A Forecasting method for future replacement demand}

The replacement requirement for a certain occupational group will in general differ in each period. Thus the replacement demand for a relatively young occupational group (automation experts for instance) may historically have been low. Over time, however, the replacement demand will probably rise because the average age in this occupational group will rise. The replacement demand for an occupational group can also depend on several more or less external factors, such as trade cycles or changes in the participation rate of the potential labour force. In making forecasts, these effects must therefore be taken into consideration.

To simplify the matter, let us assume for the time being that the occupational group for which the future replacement demand has to be determined is a growth group ${ }^{5}$. The future replacement requirement is therefore equal to the sum of the expected outflows, for all age groups, from this occupational group.

5. The replacement demand for declining groups will be considered later in this section. 
The observed outflow figures can be converted to yearly outflow ratios for the various age categories of the occupational group in question ${ }^{6}$. If the duration of the historical period $(t-1, t)$ is $D_{1}$ years, then:

$g O_{j t}^{*}=\left|\min \left\{0 ; g W_{j t}\right\}\right|$

and:

$g W_{j t}=\sqrt[D_{1}]{\frac{W_{j+1 t}}{W_{j t-1}}}-1$

where:

$\mathrm{gO}^{*} \mathrm{jt}$ the average yearly net outflow ratio of workers of age $\mathrm{j}$ at time $\mathrm{t}-1$, from a certain occupational group, during period $(t-1, t)$. This ratio is defined as a non-negative figure ${ }^{7}$.

Equations (23) and (24) can be explained using the example presented in the previous section. If $D_{1}=6$, it follows from equation (24) that for occupational group 1 :

$$
\begin{aligned}
g W_{1 t} & =\sqrt[6]{\frac{220}{150}}-1 \\
& =0,066
\end{aligned}
$$

$$
\begin{aligned}
g W_{2 t} & =\sqrt[6]{\frac{35}{200}}-1 \\
& =-0,25
\end{aligned}
$$

6. The specification of annual ratios appears to be useful, in relation to the corrections for trade cycle effect and degree of participation which will be dealt with below, and a possible difference in length between the period of observation and the period of the forecast.

7. For a net outflow for a certain age category from an occupational group, $W_{j+1 t}<W_{j t-1}$ and therefore $\mathrm{gW}_{\mathrm{jt}}<0$. In order to define the outflow ratio as non-negative, equation (23), in contrast to equations (16) and (17), is written as the absolute value of a minimalization problem. 
and thus, from equation (23), it follows:

$g O_{1 t}^{*}=0$

$g O_{2 t}^{*}=0,25$

Of course the outflow of workers who were of age category 3 at time $t-1$ is $100 \%\left(\mathrm{gO}_{3 t}=1\right)$.

\section{Correction for trade cycles}

If, in an historical period, economic activity has been at a low point in the cycle, the flow of those that had been working in the occupational group in question into unemployment or out of the group of working persons will have been relatively large. The portion of the labour force who are working has decreased. If one supposes that the trade cycle manifests itself to the same degree in all occupational groups, then the historically measured net outflow ratio for every group will be influenced by the economic recession: this ratio will therefore have been over-estimated, from a structural point of view. In order to make the forecast of the future replacement demand 'cyclically neutral', the outflow ratio will have to be corrected. The correction factor will be the difference between the change in the total number of working persons and the change in the total labour force. The cyclical correction will differ for each age category, to allow for the fact that the effects of the economic cycle are usually not the same for all age groups.

Define:

$g W P_{j t}=\sqrt[D_{1}]{\frac{W P_{j+1 t}}{W P_{j t-1}}}-1$

$g L F_{j t}=\sqrt[D_{1}]{\frac{L F_{j+1 t}}{L F_{j t-1}}}-1$

where:

$\mathrm{gWP}_{\mathrm{jt}}$ the average yearly growth ratio of the total number of working persons of age $\mathrm{j}$ at time $\mathrm{t}-1$ during the period $(\mathrm{t}-1, \mathrm{t})$;

$\mathrm{gLF}_{\mathrm{jt}}$ the average yearly growth ratio of the total labour force of age $\mathrm{j}$ at time $\mathrm{t}-1$ during the period $(t-1, t)$; 
$W P_{j t} \quad$ the total number of working persons of age $\mathrm{j}$ working at time $\mathrm{t}$;

$\mathrm{LF}_{\mathrm{jt}} \quad$ the total labour force of age $\mathrm{j}$ at time $\mathrm{t}$.

The data on the number of working persons and on the size of the labour force are taken from the Labour Force Survey of the CBS, already mentioned, and Op de Beke (1987), respectively. The total number of working persons, for each age category, is equal to the sum of the number of workers in all the occupational groups:

$$
W P_{j t}=\sum_{i} W_{i j t}
$$

To determine the future outflow figures, the historically measured net outflow figures per occupational group are corrected for cyclical influences. This (additional) correction is such that the future net outflow is lower if there has been an economic recession during the period of observation, that is, if the labour force has grown faster than the number of working persons. The correction can therefore be written as:

$$
g W P_{j t}-g L F_{j t}
$$

\section{Correction for the degree of participation}

Changes in the age structure of a certain occupational group are also dependent on changes in the degree of participation of the different age groups in the total labour force. It is therefore obvious that this effect should also be included in the modelling of the future replacement requirement.

The applied correction for the participation degree is:

$g L F_{j t}-g L F_{j t+1}$

In equation (29) $\mathrm{gLF}_{\mathrm{jt}}$ represents the change in the participation of the potential labour force of age $j$ at time $t-1$, during the period $(t-1, t)$, whereas $g L F_{j t+1}$ is the expected change in the participation of the labour force of this age during the period $(t, t+1)$. The difference between the two terms therefore gives the effect of the expected change in the participation rate of the potential labour force on the outflow of workers. If the participation degree of a certain age 
category is expected to decrease in the future, the correction factor presented above is positive, and so the net outflow of workers of that age as a result of this development is higher than in the historical period.

If the outflow ratios for a certain age group in the past have been 0 or 1 , the same ratio may be supposed for the future. If the cyclical correction and the participation degree correction are combined, the (corrected) future outflow ratio by age categories $\left(\mathrm{gO}_{\mathrm{jt}+1}^{*}\right)$ will be:

$$
\begin{aligned}
g \hat{O}_{j t+1}^{*} & =g O_{j t}^{*}+g W P_{j t}-g L F_{j t}+g L F_{j t}-g L F_{j t+1} & & \\
& =g O_{j t}^{*}+g W P_{j t}-g L F_{j t+1} & & \text { if } \quad 0<g O_{j t}^{*}<1 \\
g \hat{O}_{j t+1}^{*} & =g O_{j t}^{*} & & \text { otherwise }
\end{aligned}
$$

With the aid of this expected future outflow ratio we can forecast the future net outflow per occupational group:

$$
\hat{O}_{j t+1}^{*}=W_{j t}\left(1+g \hat{O}_{j t+1}^{*}\right)^{D_{2}}
$$

where:

$\hat{O}^{*}{ }_{\mathrm{j}+1}$ the expected net outflow of workers of age $\mathrm{j}$ at time $\mathrm{t}$ during the forecast period $(t, t+1)$;

$D_{2} \quad$ the duration of the forecast period

If employment in an occupational group has risen in the period $(t-1, t)$, the sum of the expected net outflows for the age categories will give a forecast for the future replacement demand in the occupational group in question. On the contrary, however, if the level of employment has fallen during the period, the replacement demand is equal to the total net inflow. Since the future inflow according to age and sex is not known, the expected replacement demand in this case has to be determined by the net outflow, corrected for the negative change in the level of employment (see also equation (22)):

$$
R D_{t+1}=\sum_{j} \hat{O}_{j t+1}^{*}+\left(\sum_{j} \hat{W}_{j t+1}-\sum_{j} W_{j t}\right)
$$

with: 
$\sum_{j} \hat{W}_{j t+1}=\left(\sum_{j} W_{j t}\right)\left(g W_{t}-g W P_{t}+g L F_{t+1}\right)$

where:

$\Sigma_{\mathrm{j}} \hat{\mathrm{W}}_{\mathrm{jt}+1}$ an (implied) forecast of the number of workers in this occupational group at time $t+1$;

$\mathrm{gW}_{\mathrm{t}}$ the average yearly growth ratio of employment in the occupational group in question during the period $(t-1, t)$;

$\mathrm{gWP}_{\mathrm{t}}$ the average yearly growth ratio of the total number of working persons during the period $(t-1, t)$;

$\mathrm{gLF}_{\mathrm{t}+1}$ the expected average yearly growth ratio of the total labour force during the period $(t, t+1)$.

Equation (32) shows that the expected future replacement demand is the sum of the expected net outflow and (negative) future changes in the level of employment. It should be noted that the 'forecast' for future employment per occupational group is based on an extrapolation model, corrected for the cyclical and demographic developments, and is not based on employment forecasts using the occupational model (see equation (33)). Since the expected outflow figures are determined with this extrapolation method as well, this gives a consistent 'correction' for future changes in the level of employment.

\subsection{The forecast results}

The expected future replacement requirement can be determined using the forecasting method which has been developed in this chapter. As has been mentioned before, the data consisted of the age structure of the workers for the years 1979 and 1985, by occupational classes. On this basis we made forecasts for the period 1989-1994.

The average replacement demand per occupational group in the period 1989-1994 is around $12 \%$ of the number employed in 1989, varying from $22 \%$ for professional soldiers and fishermen, hunters and related workers to $2 \%$ for statisticians, system analysts and related workers and government executive officials. Because the amount of data involved is massive, a complete review of the comparative forecasts of replacement demand by occupational group is given in Appendix $A^{9}$. A comparative qualitative characterization has assigned to the

8. This implies a forecast for the replacement demand in the period 1985-1989.

9. No forecasts of the future replacement demand for the occupational groups 'mining, quarrymen, well drillers etc.', jewellery and precious metal workers' and 'operators of RTV, emission, sound and vision equipment' are given. The results for these occupational groups may well be distorted because so many cells are empty or nearly so. 
$-16-$

replacement demand percentages for each occupational group (see Wieling, De Grip and Willems, 1990). It should be noted once more that the replacement demand and the expansion demand together comprise the number of 'job-openings' in the period 1989-1994, which is an indication of the likelihood of finding a job in the occupational group concerned during the forecast period. 


\section{REPLACEMENT DEMAND BY EDUCATIONAL TYPE}

The replacement demand by type of education, like the demand by occupational groups, can be determined. The two concepts must however be interpreted differently. As has been said in chapter 3 , the replacement demand per occupational group and the expansion demand together indicate how easily newcomers on the labour market may find a job in the occupational group concerned. The net mobility between occupational groups is therefore taken into account: when an employee leaves for another occupational group, there is a replacement demand in the occupational group he or she has left. When determining the replacement demand per type of education, however, this occupational mobility is not taken into account. When an employee with a certain educational background changes occupational group, this does not, on balance, create a new job for a newcomer with the same educational background. The replacement demand for a certain occupational group which is created by this occupational mobility is balanced by an equal flow of labour into another occupational group.

There is another difference between the replacement demand by occupational group and by type of education. If someone leaves a certain occupational group and is replaced by an employee with another (e.g. higher) educational background, there is a replacement demand for the occupational group in question. When such displacement or substitution effects occur, however, there is no question of replacement demand for the training types in question, but rather of a negative expansion demand for one group and a positive expansion demand for the other (see Beekman, Dekker, De Grip and Heijke, 1989).

For the rest, the method for determining the replacement demand by type of education is analogous to the method explained in chapter 3 . Where in chapter 3 'occupational group' is mentioned, we may read 'educational type'. The data required is the number of workers for each educational type, differentiated according to age and sex. Unfortunately the Labour Force Surveys do not provide this data at the moment. What is available are the data matrices of the number of workers per occupational group according to age and sex and the number of workers per occupational group according to type of education. With the aid of these two matrices a conversion is made, to create a matrix of the number of working persons, by type of education and according to age and sex. This can serve as a reasonably acceptable approximation to the actual data.

However, this method does not give plausible forecast results for some qualifications which are, predominantly held by women. For these types of education the fact that only the net outflow per age category is measured has a large effect. With a substantial re-entry of women, the net outflow for these types of education apparently differs to an important extent from the real 
(gross) outflow in the age group in question. For these types of education the outflow figures have been corrected on the basis of the differences in the degree of participation between age categories $^{10}$. In this way the outflow in the younger age groups in particular can be better measured.

The average forecast replacement demand per educational type in the period 1989-1994 is around $8 \%$ of the number of workers in 1989. This percentage is lower than the average replacement demand per occupational group, because, as already mentioned, the aspect of occupational mobility is not taken into account and because part of the replacement demand in an occupational group, as a result of displacement or substitution processes within the educational group concerned, is measured as expansion demand. The forecast replacement demand is highest for those with intermediate education in social care (18\%). The lowest expected replacement demand is $3 \%$ for those with security education at a lower educational level. A review of the replacement requirement per educational type can be found in appendix $\mathrm{B}^{11}$.

10. This correction was applied to the educational types for which two thirds or more of those working were women. When determining the replacement demand per occupational group no such correction was made, because the concept of degree of participation is defined per educational type and not per occupational group.

11. For three educational types which are still distinguished in the ROA-information system (lower vocational education nursing and medical services, higher vocational education dietics and nutrition, and academic education armed forces) no forecast for the future replacement demand has been given, because the results of these educational types may be significantly distorted because many cells are empty or nearly so. 


\section{CONCLUSION}

This study developed a method of determining replacement demand by occupational group and educational type. The replacement demand per occupational group gives the extent of the withdrawal of working people from a certain occupational group. A distinction can be made here between permanent departures, relating to retirement etc., and mobility to other occupational groups. The replacement demand by educational type does not take this last aspect into account and therefore is lower than the replacement demand by occupational group. The average expected replacement demand per occupational group for the period 1989-1994 is around $12 \%$ of the number of workers in 1989. For the educational types an average replacement demand of around $8 \%$ is expected.

Improvements in the method of forecasting future replacement demand are desirable. In particular, there is a need for better data to determine the replacement demand per educational type. However, further study will have to be done into the method applied and the possible alternatives. 


\section{REFERENCES}

Allaart, P.C., R. Kunnen, H.A. van Stiphout (1989), Trendrapport Arbeidsmarkt 1989, OSAvoorstudie V32, 's-Gravenhage.

Beekman, Th.B.J., R.J.P. Dekker, A. de Grip, J.A.M. Heijke (1989), An Explanation of the Educational Structure of Occupations, ROA-W-1989/3E, Maastricht.

Beke, J.M.J. op de (1987), Herziening trendmatig arbeidsaanbod 1985-2000, Centraal Planbureau, Interne notitie NOT8710.0, 's-Gravenhage.

Centraal Bureau voor de Statistiek (1982), Arbeidskrachtentelling 1979, Voorburg/Heerlen.

Centraal Bureau voor de Statistiek (1987), Arbeidskrachtentelling 1985, Voorburg/Heerlen.

Dekker, R.J.P., A. de Grip, Th.B.J. Beekman, P.J.E. van de Loo, M.H. Wieling, E.J.T.A. Willems (1990), Rapportage I-See! 1990, ROA-R-1990/6, Maastricht.

Dekker, R.J.P., A. de Grip, J.A.M. Heijke (1988), An Explanation of the Occupational Structure of Sectors of Industry, ROA-W-1988/2E Maastricht.

Peeters, H.M.M. (1990), An Explanation of the Occupational and Educational Structure by Means of Multinomial Logit, ROA-W-1990/4E, Maastricht.

ROA (1990), Het informatiesysteem onderwijs-arbeidsmarkt; onderzoekprogramma 1990/1991, ROA-R-1990/4, Maastricht.

Wieling, M.H., A. de Grip, E.J.T.A. Willems (1990), Een systematische kwalitatieve typering van arbeidsmarktinformatie, ROA-W-1990/8, Maastricht. 


\section{APPENDIX A: RESULTS REPLACEMENT DEMAND BY OCCUPATIONAL GROUP}

Table 2. Replacement demand per occupational group 1989-1994

Occupational group

Replacement demand

$\%$

Relatively very high

Professional soldiers

Fishermen, hunters and related workers $\quad 22$

Farm managers and supervisors $\quad 21$

Metal processors $\quad 20$

Telephone and telegraph operators $\quad 20$

\section{Relatively high}

Workers in religion

Salesmen, shop assistants and related workers $\quad 19$

Agricultural workers $\quad 18$

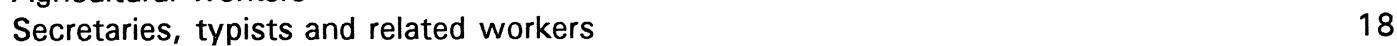

$\begin{array}{ll}\text { Launderers, dry-cleaners and pressers } & 18\end{array}$

Sales supervisors and buyers $\quad 17$

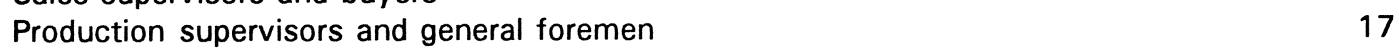

$\begin{array}{lr}\text { Housekeeping and related service supervisors } & 16\end{array}$

Rubber and plastic product makers 16

Physical scientists and related technicians $\quad 16$

Food and beverage processors $\quad 16$

\section{Average}

Maids and related housekeeping workers $\quad 15$

Working proprietors (catering and lodging services)

Professional sportsmen and related workers 14

Computing machine operators $\quad 14$

Service workers n.e.c. $\quad 14$

Printers and related workers $\quad 14$

Hairdressers barbers, beauticians and related workers $\quad 14$

Cooks, waiters, bartenders and related workers 14

Machinery fitters, machine assemblers and related workers $\quad 14$

Shoemakers and leather goods makers $\quad 14$

Blacksmiths, toolmakers and machine tool operators 14

Insurance, real estate securities and business services, salesman and auctioneers $\quad 14$

Aircraft and ship's officers $\quad 14$

Bookkeepers, cashiers and related workers $\quad 13$

$\begin{array}{ll}\text { Transport equipment operators } & 13\end{array}$

Stationary engine and related equipment operators 13

$\begin{array}{ll}\text { Farmers } & 13\end{array}$

Sculptors, painters, photographers and related creative artists $\quad 12$

Clerical and related n.e.c. $\quad 12$

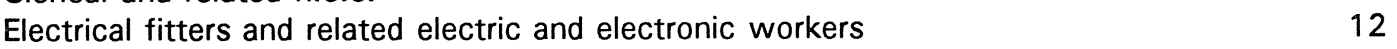

Wood preparation workers and paper makers $\quad 12$

Material handling and related equipment operators, dockers and freight handlers 12

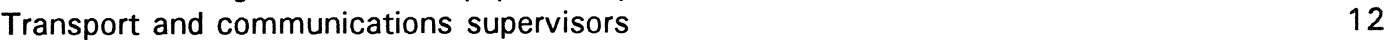

Plumbers, welders sheet metal and structural preparers and erectors $\quad 11$

Chemical processors and related workers $\quad 11$

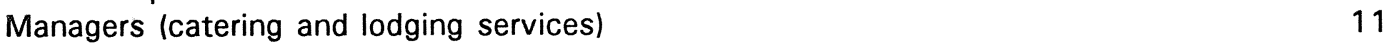

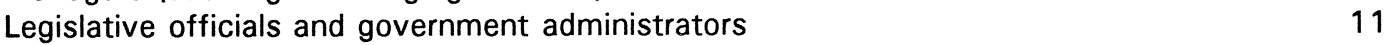

Paper and paperboard product makers 
Table 2. Replacement demand per occupational group 1989-1994 (continued)

Occupational group

Replacement demand

$\%$

Accountants

10

Economists

10

Glass formers, potters and related workers $\quad 10$

Building caretakers, cleaners and related workers 10

Spinners, weavers, knitters, dyers and related workers 10

Technical salesmen, commercial travellers and manufacturer's agents 10

\section{Relatively low}

Life scientists and related technicians 9

Managers (retail trade) 9

Tailors, dressmakers and related workers

Managing and higher executive functions exclusive of public administration 9

Composers and performing artists

$\begin{array}{lr}\text { Architects, engineers and related technicians } & 8\end{array}$

Medical, dental, veterinary and related workers $\quad 8$

Jurists

\begin{tabular}{lr} 
Teachers & 8 \\
\hline
\end{tabular}

Clerical supervisors $\quad 8$

Bricklayers, carpenters and other construction workers $\quad 8$

Professional, technical and related workers $\quad 8$

Working proprietors (wholesale)

Protective service workers

$\begin{array}{ll}\text { Transport conductors } & 7\end{array}$

Managers (wholesale)

Painters

Shopkeepers, streetvendors $\quad 7$

Production and related workers $\quad 6$

Forestry workers 6

Mail distribution clerks $\quad 6$

\section{Relatively very low}

Labourers n.e.c.

Authors, journalists and related workers

Cabinetmakers, woodworkers and related workers

Tobacco preparers and tobacco product makers 4

Statisticians, system analysts and related workers

Government executive officials $\quad 2$ 


\section{APPENDIX B: RESULTS REPLACEMENT DEMAND BY EDUCATIONAL TYPE}

Table 3. Replacement demand per educational type 1989-1994

Educational type

Replacement demand

$\%$

\section{Relatively very high}

Intermediate Vocational Education, Social Care 18

Lower Vocational Education, Social Care \& Catering 15

Academic Education, Theology $\quad 15$

Intermediate Vocational Education, Medical Services 14

\section{Relatively high}

Lower Vocational Education, Technical

Intermediate Vocational Education, Nursing $\quad 12$

Lower Vocational Education, Economic \& Administrative 11

Intermediate Vocational Education, Medical Laboratory 11

Higher Vocational Education, Theology 11

\section{Average}

Lower General Secondary Education

Intermediate Vocational Education, Catering \& Hairdressing 10

Lower Vocational Education, Transport \& Harbour $\quad 9$

Intermediate Vocational Education, Administration \& Legal \& Fiscal 9

Higher Vocational Education, Air force \& Marine \& Traffic $\quad 9$

Higher Vocational Education, Medical Laboratory $\quad 9$

Lower Vocational Education, Agriculture $\quad 8$

Intermediate Vocational Education, Agriculture $\quad 8$

Intermediate Vocational Education, Police \& Fire Brigade \& Defense 8

Intermediate Vocational Education, Technical \& Laboratory $\quad 8$

Higher Vocational Education, Teacher Training 8

Higher Vocational Education, Catering $\quad 8$

Higher General Secondary Education $\quad 7$

Intermediate Vocational Education, Social \& Cultural

Intermediate Vocational Education, Transport \& Harbour \& Telecommunications $\quad 7$

Higher Vocational Education, Agriculture $\quad 7$

Higher Vocational Education, Administration \& Legal \& Fiscal $\quad 7$

Higher Vocational Education, Art $\quad 7$

Higher Vocational Education, Police \& Fire Brigade \& Defense $\quad 7$

Academic Education, Mathematics \& Natural Sciences $\quad 7$

\section{Relatively low}

Primary education

Higher Vocational Education, Social \& Cultural $\quad 6$

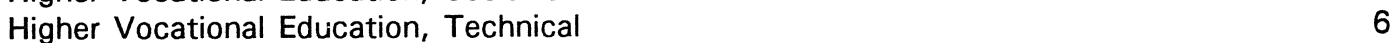

Academic Education, Agriculture $\quad 6$

Academic Education, Economics \& Business Administration $\quad 6$

Academic Education, Law \& Public Administration $\quad 6$

Academic Education, Social Sciences $\quad 6$

Academic Education, Technical Sciences $\quad 6$

Intermediate Vocational Education, Economics \& Administration

Higher Vocational Education, Business Administration Technology

Higher Vocational Education, Technical \& Laboratory $\quad 5$

Higher Vocational Education, Interpreter \& Translator $\quad 5$

Academic Education, Fine Arts 
Table 3. Replacement demand per training type 1989-1994 (continued)

Educational type

Replacement demand $\%$

Academic Education, Literature \& History etc.

Relatively very low

Intermediate Vocational Education, Sports Teacher \& Recreation

Higher Vocational Education, Economic \& Administrative

Higher Vocational Education, Nursing \& Physiotherapy etc.

4

Academic Education, Veterinary, Medical Science \& Dentistry

4

Academic Education, Teacher Training

Academic Education, Econometrics \& Business Administration

4

Academic Education, Pharmacy

Lower Vocational Education, Security

Source: ROA 


\section{REPLACEMENT DEMAND: A THEORETICAL FRAMEWORK}

In the labour market, mobility processes may be observed continuously. Many employees change occupation or job several times during their working life ${ }^{1}$. Moreover, every year a considerable number of people enter or leave the work force. Therefore a typical career path might begin with leaving regular day-time education and entering the work force, possibly after a period of unemployment. After having changed jobs several times, possibly with some periods of unemployment or a temporary withdrawal from the labour market, the worker finally leaves the work force later in life.

Figure 1. Input-output table showing currents of mobility in the labour market.

\begin{tabular}{|c|c|c|c|c|c|}
\hline$t-1$ & $\begin{array}{llll}\text { Job1 } & \ldots . . & \text { Job I }\end{array}$ & Unemployed & $\begin{array}{l}\text { Outside } \\
\text { labour force }\end{array}$ & $\begin{array}{l}\text { Outflow } \\
\text { population }\end{array}$ & Total \\
\hline $\begin{array}{c}\text { Job } 1 \\
\cdot \\
\cdot \\
\cdot \\
\cdot \\
\text { Job I }\end{array}$ & $\begin{array}{ll}\text { A } & \text { B } \\
& \\
\text { E } & \end{array}$ & $\mathrm{C}$ & D & & $\begin{array}{c}\mathrm{W}_{1-1-1} \\
\cdot \\
\cdot \\
\cdot \\
\mathrm{W}_{\mathrm{It}-1}\end{array}$ \\
\hline $\begin{array}{l}\text { Unemployed } \\
\text { Outside } \\
\text { labour force }\end{array}$ & $\begin{array}{l}\text { F } \\
\text { G }\end{array}$ & & & & \\
\hline $\begin{array}{l}\text { Inflow } \\
\text { population }\end{array}$ & & & & & \\
\hline Total & $\mathrm{W}_{\mathrm{lt}} \ldots . . \quad \mathrm{W}_{\mathrm{lt}}$ & & & & \\
\hline
\end{tabular}

In figure 1 an input-output table for the entire population is presented, in which the mobility processes described above are schematically reproduced at an aggregated level. The last column of the input-output table gives the number of workers at time $\mathrm{t}-1$ in each of the 'jobs' ${ }^{2}$ which have been differentiated, and also the number of unemployed and non-active people at the same moment. The last row of the table gives the same figures, for time $t$. In addition, the last column of the table gives the total population influx as a result of birth and immigration,

1. According to Allaart, Kunnen and Van Stiphout (1989) the total occupational mobility in the period October 1987 to October 1988 was $13 \%$.

2. In the practical application of this theoretical framework, occupational group and type of education replace the term 'job'. 